and that constitutes a kind of religion in the intellectual order, cannot be the stuff of science. Metaphysics is the supreme synthesis that hovers above science and frequently loses contact with it. It remains the responsibility of a talented individual, sometimes of a genius, but always of a self-conscious individual. There is nothing like that kind of intellectual training to elevate the soul, to better satisfy the spirit, even though, as often happens, it leads to tragic disappointment.

There are, however, works of coordination, attempts to summarize knowledge, that do have their entire basis in science, and one department in the School of Advanced Studies classifies it under the title of philosophy. There we will open courses in the history of philosophy, beginning with the history of modern doctrines and new systems, or renovated systems, from the appearance of positivism to today, to the days of Bergson and William James. And we will leave open, completely free, the fields of negative or positive metaphysics, pluralism as well as monism, so that we are made to think and feel while pursuing the pure vision of those eternal ideas that forever appear and reappear in the course of intellectual life-a God distinct from the universe, a God immanent in the universe, a universe without God.

What would we have achieved if, upon realizing this dream we completed, with a Mexican star, an asterism that did not shine in our sky? No, the new man, whom the dedication to science turns into a young neophyte who has the lifeblood of his soil and the blood of his people in his veins, cannot forget to whom he is indebted and to whom he belongs. The sursum corda that issues from his lips to the foot of the altar should be directed to those who have loved with him, to those who have suffered with him. Let him hold up before them, as a promise of liberty and redemption, the immaculate host of truth. We do not want in the temple erected today an Athena without eyes for humanity, and without a heart for the people, within her contours of white marble. We want the best Mexicans to come here with incessant theories to worship the Athena Promachos and the science that defends the homeland.
CHAPTER 3

\section{Existence as Economy and as Charity}

\author{
AN ESSAY ON THE ESSENCE OF \\ CHRISTIANITY (1916) \\ - \\ Antonio Caso \\ Translated by Alexander V. Stehn and \\ Jose G. Rodriguez, Jr.
}

Antonio Caso Andrade was born in Mexico City in 1883 and died in the capital in 1946. Like several other members of the Ateneo de la juventud, he studied at the National Preparatory School and then studied law at the School of Jurisprudence, where he later became professor of sociology in 1909 (while also teaching philosophy at the National Preparatory School). After Justo Sierra founded the National University in 1910, Caso became a professor of philosophy in, and would eventually direct, the School of Higher Studies, which would later become the Faculty of Philosophy and Letters. In addition to being a charismatic professor who inspired an entire generation of philosophers in Mexico, he also served in administrative roles, as rector of the National University (1920-1923) and as a founding member of the now prestigious College of Mexico (Colegio de México, founded in 1942). Among his many publications on a wide variety of themes, the following are especially relevant to the question of Mexican identity and philosophy: Discursos a la nación mexicana (Discourses on a Mexican Nation, 1922), El problema de México y la ideología nacional (The Problem of Mexican and National Ideology, 1924), La persona humana y el estado totalitario (The Human Person and the Totalitarian State, 1941).

Struggle for life.

$$
\text { -Darwin }
$$

All bodies, the firmament, the stars, the earth and its kingdoms, are not worth the least of minds. For mind knows all of these, and itself, and bodies know nothing.

All bodies together, and all minds together, and all their productions, are not worth the least movement of charity....

-Pascal 
To my disinterested friends: Don Julio Corredor Latorre, Consul General of the Republic of Columbia in Mexico, and Dona Clotilde Quijano de Corredor Latorre.

\section{Preface}

A short time ago, the author of this brief essay was invited to give a series of lectures at the Mexican Popular University, a free institution of education founded by the Athenaeum of Mexico for the diffusion of culture. The author thought of offering his audience a synthesis of Christianity gathered from the moral biography of some great Christians. Such a synthesis would have to be-to use Carlyle's beautiful expression now consecrated by use, a worship of heroes and the heroic in history ${ }^{1}$-dedicated to the most important event in the evolution of humanity: the development of evangelical ideas and feelings over time.

In summary form, here are the great representative figures of Christian evolution to bear in mind, along with a rough indication of their symbolism:

Saint John the Baptist is the precursor, the seer idealized by the beautiful evangelical legend, interpreted in the contemporary art of Gustave Flaubert, Oscar Wilde, and in the music of Strauss. Situated between the Old and the New Testament, John the Baptist appears as Israel's last prophet and the world's first Christian. He is a fierce heroic figure who possesses the majestic solitude of the desert.

Saint Paul is the apostle, the practical author of Christianity (someone has spoken of Paulism) as a universal and not simply Jewish phenomenon. The apostle common to Catholicism and Protestantism, Paul is the eternal symbol of religious conversion, of the twice-born that William James discusses in his philosophy of religion.

Saint Augustine is the father of the Church. He represents this incalculable event: the alliance of the humanities and classical culture with divine inspiration, opposing the skeptics of his time with the victorious Cartesian argument that gave birth to modern philosophy. Catholicism, Protestantism, and Cartesianism: he intuits or paves the way for all of them. He is one of humanity's most richly gifted minds [los espiritus].

Charlemagne, the emperor of the flowery beard (according to the Song of Roland) and immortal soldier of the Church, confirms the feudal Catholic regime on Christmas Eve in the year 800 by creating the temporal power of the popes. He is the medieval king par excellence, the leader of the barbarian West, Christian and Roman, the main character of the chivalrous epic.

${ }^{1}$ [Scottish philosopher and essayist Thomas Carlyle (1795-1881). Caso's remark refers to On Heroes, Hero-Worship, and The Heroic in History (1841).-Trans.]
Gregory VII is the pope, a monk who dons the crown and brings to Europe's throne the austere virtues of the cloister and the incorruptible zeal of Christ's true vicar. He represents, as Guizot says, the theocratic and monastic Church.

Saint Francis of Assisi is the mystic, sweet and generous, of the Beatitudes; the hero of feeling and simple charitable action; Christianizer not only of humanity, but also of nature as a whole; the favored son of Jesus Christ. He is the symbol of expansive, contagious, boundless Christian joy.

When the Renaissance seems to resurrect paganism as victorious despite the triumph of civilization, Luther, the intrepid disciple of Saint Paul and Saint Augustine, opposes the Renaissance with the Reformation, opposes what seemed to be the apotheosis of the classical world with the apotheosis of the Christian idea, intimately united with the spirit of free inquiry characteristic of modern times. And what the rebellious German friar represents outside of the Catholic Communion, Saint Teresa represents inside the bosom of the Church with the most genuinely orthodox piety. She is the simultaneously brilliant and submissive Christian woman, the tireless reformer (of the traditional Catholic type), and founder of the universal society of spirits and hearts. Teresa is the saint by antonomasia.

Pascal and Tolstoy are history's latest great Christians. Pascal is the personification of literary, scientific, and philosophical genius, who sacrifices intellectual vanity to the ineffable good of grace. He is the enlightened one who, while capable of the most profound rationality, is subsequently convinced that any rationality that does not lead to Jesus Christ is nothing compared to action, nothing compared to the feeling of humanity. Nietzsche gave him the highest praise by calling him the most instructive victim of Christianity.

Tolstoy launches the Christian anathema against people in power, against social and political institutions, against blood-stained patriotism and militarism:

The relation between the men who command and those who obey forms the essence of the concept of power. Without the exaltation of oneself and the humiliation of others, without hypocrisy and deceit, without prisons, fortresses, executions, and murders, no power could come into existence or be maintained. ${ }^{2}$

${ }^{2}$ [Russian writer and religious theorist Leo Tolstoy (1828-1910). The quote is from Tolstoy's The Kingdom of God ls Within You (1894). The first sentence appears to be a paraphrase, but the second is a quotation.-Trans.] 
Tolstoy is an exemplar of this other Christian heroism, anarchism, that considers ordering and obeying to be equally vile.

This is, synthetically, Christianity in the history of humanity: the Precursor, the Apostle, the Father of the Church, the Medieval Emperor, the Pope, the Mystic, the Reformer, the Saint, the Jansenist, the Anarchist-and along with them, holiest of all, the glorious and innumerable legion of martyrs.

Once this plan of labor was defined, the projected lectures were developed over the course of roughly three months. And from dealing with what history has to say about the example and doctrine of the great Christians, my final plan was born: an interpretation of the essence of Christianity. This humble interpretation, in the eyes of the author, does not in any way contradict the philosophical and scientific conclusions of our time. It is offered to the reader in what follows with the title Existence as Economy and as Charity.

\section{Existence as Economy and as Charity}

To be is to struggle, to live is to conquer, according to Le Dantec. It is interesting to recognize that nothing has been investigated that was empirical [positivo] and congruent with respect to life and its manifestations, except when it was conceived as struggle. Without consenting to the synthetic expression of the French biologist, without subscribing to his philosophical thesis of universal struggle, or in other words, without speaking his language, it is nevertheless necessary to admit that, if not all being, then at least the living being is defined by the idea of struggle. To struggle and to live are synonymous. Life, in its economy, is a triumph over the environment, over the enemy, or over the fellow man, who, by the similarity of his necessities and organization, is the enemy by another name.

Since Darwin, the economy of nature has been the supreme principle of biology. We know that Malthus's celebrated economic theory, founded on the disproportion between the food supply and population growth, inspired Darwin's thesis of natural selection.

The economist's thesis is too narrow for the super-organic world. Like all of the other theses of classical political economy, it has not been proven by history. In contrast, Darwin's theory is still the common axis of biological discussion today, the scientific theory or law that unites (like a bridge, as [John] Stuart Mill would say) and coordinates the diverse chapters of the study of living beings.

There is nothing obscure, nothing mythical, in Darwin's explanation. Some living beings prosper and develop their species through time, while others die. As J. M. Baldwin interprets Darwin:
Life is a natural selection, a selection without external intervention, that occurs with no more reason than the simple fact that some naturally survive while others die. ${ }^{3}$

The number of possible individuals far exceeds the actual individuals that in fact live on the earth's surface in a given moment. The germs that represent the potential of the beings endowed with life are immense in number when compared to the individuals that actually develop, especially in comparison to those that reach the age of reproduction.

Spinoza said that everything tends to persist in its being. According to Haeckel, the biological form of this tendency to preserve oneself, the drive that makes struggle necessary and provides its features, is that of individual preservation (the nutritive drive) or species-preservation (the reproductive drive). "The mechanism of the universe maintains itself through hunger and love," as Schiller sang. ${ }^{5}$

Thus, by virtue of egoism, which relies on an excess of forces to engender new kindred beings, species are established and die out. A chemical reaction produces a strictly synthetic compound from the elements that comprise it; the reaction expends itself completely in synthesis. Primitive plants and animals divide themselves to engender new beings once they reach maturity and have accumulated energy by nourishing themselves, which is to say, by adapting. Higher order animals engender their offspring by means of sexual reproduction due to functions of greater complexity. Struggle, adaptation, and heredity sustain the immense assembly of living beings. Maximum gain with minimum effort: such is the universal economy or the universal as economy. Adaptation-nutrition and heredity-reproduction, that is, hunger-is life's sole motive of action. (So-called "love"-appetite-is reduced to this elemental necessity, to sex and offspring.)

The effect of egoism over time is incalculable. In a limited, but very true sense, one could say that whatever is not egoist is stupid in the face of reason informed by scientific data. When formulating his celebrated doctrine, Malthus did not think that he was indirectly formulating a universal aspect of existence. Thanks to Darwin, political economy has become the economy of the entire world.

Egoist or economic activity is so real that it even explains some seemingly unrelated activities, and it gains in certainty and extension when they are

${ }^{3}$ Le Darwinisme dans les sciences morales, p. 5. [Trans. note: Guillaume Léonce Duprat's 1911 French translation of James Mark Baldwin, Darwin and the Humanities (Baltimore, MD: Review Publishing, 1909).]

${ }^{4}$ Historia de la creación natural, p. 156 of C. Litrán's Spanish translation. [Cristóbal Litrán's 1905 Spanish translation of Ernst Haeckel, Natürliche Schöpfungsgeschichte (1868), translated into English as The History of Creation, 2 vols. (New York: D. Appleton, 1876).-Trans.]

${ }^{s}$ [German poet and philosopher Friedrich Schiller (1759-1805). The line is from the poem "Die Weltweisen," which is typically translated as "The Philosophers." - Trans.] 
explained. Human industry is the very definition of man's intelligence. According to Bergson, we should say homo faber instead of homo sapiens. ${ }^{6}$ Intelligence, an elegant solution to the problem of life (as the great French thinker says), is the faculty of creating tools, instruments of action. And science, which at first glance is a disinterested knowledge, has as its objective:

$[t] \mathrm{o}$ order sense data, to investigate with all possible economy of thought the relations of dependence that exist between sensations, and to realize a structure so uniform that intellectual fatigue can be avoided. Scientific knowledge implies the description, that is, the mental imitation of a fact, and this description should be able to replace experience and economize it. ${ }^{7}$

This is Science, or rather, the sciences (in the plural without capital letters).

Science is the same biological interest, subtler and more human, but no less real. The sciences are arrangements of abstract concepts that enable us to think and speak comfortably. The ideal of the sciences is to reduce themselves to Science (with a capital S), to a single discipline. And the ideal of this single Science is to reduce itself to a single truth. If there is an economic ideal, this is it: an intellectual egoism so refined and subtle that its devotees erect a monistic philosophical doctrine and decorate it with epithets of disinterest and enthusiasm. This is egoism and egoism alone.

Just as we previously saw political economy converted into universal economy, we now demonstrate that its principle of maximum gain achieved with minimum effort is converted into a systematic epistemology. According to pragmatism, scientific truth is summed up in what is advantageous for our thinking, as William James says. ${ }^{8}$ Intelligence, industry, sciences, and logic are biological forms on a Malthusian base. The only things that are neither biology nor Malthusianism are the beautiful and the good.

But before going any further, we should pause to consider the mystery of a purely biological activity that seems disinterested: play.

6 [French philosopher Henri Bergson (1859-1941). He discusses homo faber (Latin for "man the maker") in contrast to homo sapiens ("man the wise") in Creative Evolution (1907).-Trans.]

${ }^{7}$ E. Mach, La connaissance et l'erreur, p. 3. Avant-propos. [Caso's quote is from Marcel Dufour's introduction to his 1908 French translation of Mach's Erkenntnis und Irrtum (1905). The following English translation is available: Ernst Mach, Knowledge and Error: Sketches on the Psychology of Enquiry, translated by T. J. McCormack and P. Fouldes (Dordrecht, The Netherlands: D. Reidel, 1976).-Trans.]

${ }^{8}$ [US philosopher and psychologist William James (1842-1910). Caso paraphrases the conception of truth found in Pragmatism: A New Name for Some Old Ways of Thinking (1907).-Trans.]
Spencer, who was always a deficient and fussy philosopher with respect to art and beauty, once read "in a German author whose name escapes my memory" (perhaps in Schiller) the hypothesis of art referred back to play. ${ }^{9}$ And with this memory, Spencer elaborated a doctrine of aesthetic feelings that makes play the basis of art in the final chapter of his Principles of Psychology, as well as in some minor essays.

The only animals that play are those higher animals capable of accumulating more energy than their individual economy requires. Play appears to be a squandering of what one has in surplus. But if art, like play, proceeds from the dynamic surplus accumulated in life, then both activities would be nothing more in this respect than equipping oneself for the future, since artistic disinterest is not a mode of immediate struggle. And if it just so happens that all play, which seems to be carried out without an egoist impulse, is, at bottom, of the economic type, ${ }^{10}$ then play is always an imitation of struggle. In other words, play is something that mediately, if not immediately, serves interested ends.

The animal that plays, that imitates or simulates struggle with unreal adversaries, unconsciously practices struggling with real adversaries. To play is to serve the economy of life without knowing it and without deciding to do so deliberately. Life, if any remains, is spent on life. Life has no disinterest, only egoism, and that which could be given is spent or consumed in the same habitual forms of consuming and spending. All animal energy is employed in the singular ends of life, just like a machine that does not have raw material at its disposal for production ridiculously repeats for us the movements that would result in a product were the material present, as long as the force that makes it move is not extinguished.

Moreover, the higher animal, as opposed to the machine that destroys itself gradually by moving, strengthens itself for action by means of movements without a straightforward aim. Play is a beautiful paradox that might be indicated by saying that animals only know how to struggle. If they do not have anyone to struggle against, they comically imitate struggle and thus expend their surplus force. The economy of nature, upset in outward appearance, gives itself the most brilliant confirmation, the most complete satisfaction, in the facts that appear to negate it. As Goethe says on an extraordinary page of Werther:

Oh! It is neither the great and infrequent catastrophes of the world, nor the floods and earthquakes that annihilate our cities that move me. What gnaws at my heart is the devouring force that lies concealed in all

\footnotetext{
${ }^{9}$ See Principles of Psychology, The Aesthetic Feelings.

${ }^{10} \mathrm{I}$ owe this idea of assimilating play to struggle to my brother, Alfonso Caso.
} 
of nature, a force that has produced nothing that does not destroy itself and everything near it.

In this way I advance on my insecure path with anxiety. Surrounded by heaven, earth, and its active powers, I see nothing more than a monster eternally occupied by chewing and swallowing. ${ }^{11}$

The economy of nature governs the world of life and its fruits completely, like an empire. Purely biological life, industry, science, play: all of these are the diverse expression, more or less complex, of the simple mechanical axiom of the path of least resistance. Everything is summarized in this fundamental equation of the universe as economy:

\section{Life $=$ Minimum Effort $\times$ Maximum Gain}

Nevertheless, in play this important fact has already appeared: there exist living beings - higher animals - that have a surplus of energies that life does not individually claim in each being. In spite of this, because no principle of disinterested action exists in the animal, we have just seen how the vital surplus is employed in the imitation or comic parody of the struggle that drills the player and trains him for later conflicts with real enemies rather than imaginary ones.

Life, the energy of egoism that is spent resolving the complex problem of hunger, consumes itself if it does not encounter a force from a divergent order. Life alone, in surplus or excess, is finally economized as a real ability formed in exercises of movement that appear useless.

Bergson and James have observed how vital energy has a surplus that engenders fertility and abundance:

Reality, as James sees it, is abundant, superabundant. I think that the American philosopher would have established the same relation between this reality and the one that philosophers reconstruct as between the daily life that we live and the life that actors represent for us on stage at night. In the theater every actor says only what is necessary to say and does nothing except what is necessary to do. But in life we say a multitude of useless things... Things neither begin nor

${ }^{11}$ [German novelist, poet, scientist, and philosopher Johann Wolfgang Goethe (1749-1832). Caso quotes from his most famous work, The Sorrows of Young Werther (1774). Most of the novel is presented as letters written by Werther to his friend Wilhelm. The letter quoted is dated August 18.-Trans.] end. There are neither completely satisfactory endings nor absolutely decisive acts.... Such is human life and such is reality according to James. $^{12}$

This excess of living demonstrated in play canserve as a vital condition of other diverse ends of animal life, but only the surplus accumulated in man makes them achievable. The animal and the child play. Man makes works of art and carries out charitable acts. If there were no vital surplus, if man were not a privileged higher mammal, the biological condition of the aesthetic and moral order would be lacking. However, as we will see and thoroughly corroborate later, this does not mean that the good and the beautiful are equivalents or transformations of vital force. Higher animals, in being animals, spend their energy strictly on themselves; but the surplus of human energy makes man into a possible instrument of disinterested action and heroism.

No one among the wise has said such profound things concerning the economy of life and aesthetic disinterest as Schopenhauer. His pessimistic conception did not impede his genius from locating the very essence of the work of art. On the contrary, it was the reason that his philosophical speculations ascertained that in beauty there is a renunciation of the economic or animal ends of existence.

Ribot and other critics dismiss the aesthetics of The World as Will and as Representation as containing little originality. Croce scarcely does justice to the great philosopher [al gran filosofo telematista] in the historical part of the book titled The Aesthetic as Science of Expression and General Linguistics. In contrast, we believe that nothing has been written in this philosophical discipline that equals in force and truth what the great German philosopher teaches concerning the nature of the work of art and the feeling of the sublime. Bergson himself, in some of his most admirable pages on the sense and value of art, is a Schopenhauerian who freely interprets the work of the German master:

As a general rule, knowledge is always occupied in serving the will. Knowledge was born for this service and, in a sense, it has emerged from the will like the head from the body. In animals, this servitude can never be suppressed. In man, it may be suspended as an exception, as we will see in more detail in what follows....

Vulgar man, that wholesale product which nature manufactures by the thousands each day, is, as we have said, not capable, or at least not consistently capable, of completely disinterested apperception, which ultimately constitutes true contemplation. He can only direct his attention to things insofar as they have some relation to his will, however

${ }^{12}$ Le Pragmatisme, Introduction. [Bergson wrote the introduction, "Truth and Reality," to E. Le Brun's 1911 French translation of William James's Pragmatism.-Trans.] 
indirect the relation may be. And from this point of view, which never demands more than the knowledge of relations, the abstract notion of the thing is sufficient and even preferable in the majority of cases. Vulgar man does not linger over the pure intuition, does not fix his gaze on an object for long, but instead hastily seeks the concept under which he may bring everything presented to him, like the lazy man seeks a chair, and then it is no longer his concern.

How could we more eloquently enrich the utilitarian, economic, egoist, and, in sum, biological essence of the concept? What else are the abstract ideas, the genera and species of logicians, the syntheses of abstract ideas that, when economized in a more abstract and general sense, constitute the sciences? In what form could we better declare that intelligence is an industry, an economy that obeys the imperative of the least effort and the most gain?

Schopenhauer adds:

Thus vulgar man immediately ceases to contemplate whatever presents itself to him: an artistic creation, a beautiful work of nature, or any aspect of eminent importance from the scenes of life. Lingering over nothing, he seeks his path through life, or, at most, that which could be his path someday, and gathers topographical information in the widest sense of the word. As for the contemplation of life itself, he does not waste his time on it. ${ }^{13}$

It has been sufficiently clarified that art is an opposition to material life, an idealism or immaterialism, a clear attitude that renounces possessing in order to consecrate oneself to contemplating. The more one renounces, the more completely one achieves an artistic spirit, to the point that if one were disinterested in all senses, one would become the supreme artist. As Bergson says,

If the detachment were complete, if the soul were no longer clinging to action by any of its perceptions, it would be an artistic soul such as the world has never seen. This artist would stand out in all of the arts at the same time, or rather, would meld them all into one. This artist's soul would perceive all things in their original purity: the forms, colors, and sounds of the material world as well as the subtlest movements of interior life. ${ }^{14}$

${ }^{13}$ The World as Will and as Representation, Volume II of the Spanish translation, p. 33. [Caso's previous block quote from Schopenhauer is from the same volume.-Trans.]

${ }^{14}$ Le rire. Quel est l'objet de l'art? [Henri Bergson, Laughter: An Essay on the Meaning of the Comic, translated by Cloudesley Brereton and Fred Rothwell (New York: MacMillan, 1914). From the section "What is the Object of Art?"-Trans.]
Art is an innate disinterest that life does not explain; art demands enormous effort and its results are useless. Works of art do not serve the economy of existence.

The essence of genius consists in a superior aptitude for contemplation. Genius is nothing other than the most complete objectivity or the objective direction of the spirit in opposition to the subjective direction aimed at one's own person, toward the will. Genius thus consists in the faculty of maintaining oneself in pure intuition, of being entirely absorbed in it, and of separating knowledge from the will it was originally put in place to serve. ${ }^{15}$

If the aristocratic tone of the German philosopher is suppressed and one remembers that the spiritual virginity that Bergson speaks of is the genuine treasure of the poor, the inheritance of the cultured and the uncultured, of ancients and moderns; if one thinks about the fact that, from the cave-dweller to the contemporary European, art has been associated with humanity throughout history and prehistory; if one remembers that - whether as creator or as imitator, as actor or as admirer, as artist or as public, great or small, strong or weak-man has never completely been the vulgar man that Schopenhauer speaks of as totally imprisoned in his subjectivity, in his absolute animality; if one bears all of these limitations in mind, then one would have to admit and endorse Schopenhauer's affirmation of aesthetic truth.

The individuals of the human species are not divided into beasts and superhumans, into vulgar men and heroes. One could truthfully say that the vulgar man only exists in the minds of vulgar men. There is an immense gradation between the modest and the great, but each person is the master of lifting his head above his body (like the Apollo Belvedere that Schopenhauer discusses) in order to employ spirit in aesthetic contemplation, instead of inclining it toward the earth in the enduring search for sustenance (like the animals do). Artistic intuition is more evenly distributed than contemporary aestheticism believes it to be.

Economy of effort cannot explain this innate disinterest or artistic individuality, whether modest or brilliant. When compared to the biological imperative of minimum effort, art appears to be a shocking waste, a violent and mysterious antithesis.

It has been observed that ideas, whose sole mission is to explain things, are also employed to negate or hide them. Mind [el espiritu] - more loving of its abstract principles, of its symbols that are comfortable for intelligence-then prefers not achieving its objective to abandoning its attitude.

${ }^{15}$ The World as Will, Volume II, p. 30. [While remaining faithful to Schopenhauer's overall meaning, Caso has rearranged the text and rewritten it slightly to mend his own omissions. - Trans.] 
The laws of adaptation, heredity, and struggle, which together produce natural selection, serve as an economic explanation of many aspects of existence, but they do not explain all of them. Nevertheless, intelligence persists in its monistic tendency, in its line of least effort, and, far from confessing its inability to explain disinterested activity by economic principles, tends to refer all experience to only one of its forms, to a single aspect of being, without remembering that reality does not exist in order to be explained by science. Rather, science exists to interpret, with the fewest possible imperfections, multiform and diverse reality.

Just as play is the biological antecedent to art, aesthetic contemplation or intuition engenders that kind of artistic feeling called the feeling of the sublime, which appears to be the closest aesthetic antecedent (not the cause) of moral activity. The sublime has been explained by Schopenhauer as a struggle between will and contemplation, between the desire to live seriously threatened by a great antagonistic force and the disinterested intuition of the object. The will is in danger, and in spite of this, it persists in contemplation. This state of consciousness is the sublime.

One notes, of course, its ethical character, its moral sense. The struggle in the sublime is between life, which wants to preserve itself above all else, and intuition, which occurs as a result of the innate disinterest that Bergson discusses. It is the conflict between subjective utilitarianism and innate idealism, the clash of two forms of existence that plays out on the stage of human consciousness. There is always a profound grandeur in the life of artists and poor geniuses, in a difficult or tragic life that sacrifices animal pleasure to disinterested contemplation. Humanity recognizes such lives as its most noble, most human exemplars, and perpetually honors them. They are sublime beings.

But the smallest act of charity is of an incomparably greater sublimity. For the artist sacrifices the economy of life to the objectivity of innate intuition, whereas the good man sacrifices egoism to come to the aid of the neighbor, to prevent his pain, and such a sacrifice is free. That is why Pascal said:

All bodies, the firmament, the stars, the earth and its kingdoms, are not worth the least of minds [los espiritus], because the mind [el espiritu] knows all of this and knows itself but bodies do not. All bodies together, all minds together, and all of their productions are not worth the least movement of charity. ${ }^{16}$

${ }^{16}$ [This fragment from Pascal's Pensées is also Caso's epigraph. Here, Caso gives his own translation (or at least, we have been unable to find a published Spanish translation that matches exactly). Caso translates Pascal's French esprit straightforwardly in Spanish as espiritu, which we in turn translate as "mind" to reflect typical scholarly discussions of Pascal's three metaphysical levels or epistemological orders: body, mind, and heart (or charity). See, for example, Graeme Hunter, Pascal the
In sum, the table of human values is this: the more one sacrifices and the more difficult it is to sacrifice merely animal life to disinterested ends-from aesthetic contemplation and ordinary good actions up to the point of heroic action - the nobler one is.

God is this spirit of sacrificing what is one's own, this sublime inspiration, this higher and more energetic life, this being-possessed, this enthusiasm (understood in its purest etymological sense), which manifests itself by carrying out acts of charity.

Disinterest, charity, and sacrifice are irreducible to the economy of nature. As Schopenhauer says, if the world were only will, the fact that the will negates itself in sacrifice would be inexplicable. The world is the will of egoism and the good will, which is, moreover, irreducible to and in conflict with the will of egoism. This experientially proves that there is another order and another life, together with the order and life that govern with the iron fist of Darwin's savage imperative: the struggle for life. The equation of the good could thus be formulated:

\section{Sacrifice $=$ Maximum Effort $\times$ Minimum Gain}

The good is not an imperative, a law of reason, as Kant thought, but rather an enthusiasm. The good never commands; it inspires. It does not impose or come from the outside; it sprouts from within intimate consciousness, from the feeling that has its roots in the profundities of spiritual existence. The good is like music that captivates and charms-easy, spontaneous, intimate-the most intimate part of the soul. It is the coercion of neither pure reason nor external life. It is neither deduced, nor inferred, nor admitted; it is created. The good is freedom, personality, divinity. It is, to sum up with the expression of an illustrious Mexican thinker, "the supernatural that feels like the most natural thing in the world." ${ }^{17}$

The three classical virtues of Christianity are in obvious agreement. Charity is neither demonstrated nor deduced. It is the fundamental religious and moral experience. It consists in going out of oneself, in giving oneself to others, in offering oneself, in making oneself available and lavishing oneself without fear of exhaustion. This is, in essence, the Christian.

Philosopher: An Introduction (Toronto: University of Toronto Press, 2013), 159-169. Our decision to translate espiritu as "mind" in this particular passage (as opposed to most other places in the text, where we translate it as "spirit") also aims to foreground a philosophical problem of interpretation: Caso's discussion of divergent "orders" of existence does not seem to line up in any straightforward way with Pascal's, in spite of the fact that the epigraph from Pascal frames Caso's entire essay. It seems that for Caso, espiritu animates all three of Pascal's orders insofar as a person's spirit moves his or her body, mind, and heart. In contrast, Pascal believes that charity is a work of the heart rather than of the mind [esprit]. In short, Pascal believes that mind [esprit] is not responsible for charity, whereas Caso believes that spirit [espiritu] is responsible for charity, which leads us to believe that they are using the same word in their own respective languages differently.-Trans.]

17 [The unnamed "illustrious Mexican thinker" is Justo Sierra (1848-1912).-Trans.] 
For this one has to be strong, personal, to be oneself, as Ibsen would say..$^{18}$ The weak one cannot be Christian, except to the extent that one's aim in being strong is to offer oneself as a center of charitable activity.

In the universe as economy, each living being is a point of centripetal action. In the universe as charity, each moral being is a point of centrifugal action.

Nietzsche's "overman" [Übermensch], conceived in all of his magnitude of sacrifice, in all of his desire to elevate life, has what the Christian has of nobility. The overman's longing for the other shore is Christianity implausibly tied to a particular biological end, not to a kind of contentment but rather to more power, which is a vile economic interest of wild ferocious beasts.

The weak one who does not want to be generous, who as a victim of sloth is not even himself, cannot be heroic; and Christianity, like art, has heroic inspirations. Just as aesthetic errors (deficient or ineffective works) do not count in the history of the arts, moral vacillations (compromises with egoism) do not count for anything in the moral biography of a Christian.

Whoever lacks a charitable will does not live according to the doctrine of Christ. How could such a person live according to Christ's teaching, if Jesus was always action, never laziness; always heroism, never making deals or compromising with evil?

The illustrious Spanish thinker Diego Ruiz has properly explained how Christian humility, far from being an attribute of the weak, is a quality of the charitable, the strong, the heroic:

I see clearly that there is no middle ground between these two primary movements called pride and humility, but I conceive of such a state, in which pride, as it is purified, is completely transformed in work. Consequently, the individual does not exist except for this work, of which he is the son, as one says precisely in Hebrew.

This is how I interpret that essentially Christian virtue of humility, which is brought together in Christ with the repeated confession of being the son of the father and of having descended in order to save us.

Each time a man goes out of himself and puts all of his pride into work, up to the point that he can feel and call himself the son of his work, I say that this man is Christian. I do not currently recognize a better explanation of the virtue of humility. ${ }^{19}$

${ }_{18}$ [Norwegian playwright and poet Henrik Ibsen (1828-1906). Caso is presumably referring to this line from his play, Peer Gynt: "To be oneself is to slay oneself."-Trans.]

${ }^{19}$ [The quoted passage is from Jesus as Will: Dialectic of Christian Belief (1906).-Trans.]
Humility is the other face of Christian charity and heroism. How could someone who is only conscious of himself to the extent that he collaborates in the work of the good fail to be humble? How will he who gives to others to the point of annihilation have pride? What would be the purpose of having pride? What would he be proud of? If he were proud, his feeling that he was keeping something for himself would be a sign that something spiritual had remained inactive, slothful, inert. He would not have been Christian to the extent that he failed to dedicate himself to liberating action.

Like struggle, charity is a fact. It is not demonstrated, it is practiced, it is made, like life. It is another way of life. You will never have the intuition of an order that is opposed to biological life, you will not understand existence in its profound richness, you will mutilate it beyond remedy, if you are not charitable. ${ }^{20}$ Fundamental intuitions must be lived. He who does not sacrifice himself does not understand the whole world, nor is it possible to explain it to him, just as it is impossible to explain what sound is to a deaf person, or what light is to a person blind since birth. There is neither sight for the blind, nor hearing for the deaf, and neither morality nor religion for egoists. That is why you see egoists denying them. But just as the deaf person does not disprove the existence of music and the blind person does not disprove the existence of painting, the evil person does not disprove the existence of charity, the incomparable work of art. In order to comprehend existence as economy and as charity, as disinterest and as sacrifice, it is necessary to have all the facts and to consider man in his integrity as neither angel nor beast.

Faith is the confirmation that-alongside the world ruled by the natural law of life-there is a world ruled by the supernatural law of love. ${ }^{21}$ The good is a contradiction in the face of life. For the believer, life is a pain that must be relieved, a pain that is essential to relieve. Life always wants and the good always gives. Believing in God is a direct consequence of doing good. If you are not charitable, you will not be believers.

"Only faith saves," says the Reformer. This is not true. Faith is impossible without charity, as light is impossible without the sun, as the corollary is impossible without the axiom. Because the corollary is in a way the axiom, but the axiom exists by itself; and the sun is in a way light, but the sun is the source and light its gleam —although

${ }^{20}$ [Each of the four verbs that appear in this sentence are written in the second-person plural, which has not appeared previously. This grammatical person, the formal but nonetheless personal addressee of Caso's message on charity, crescendos up through the subsequent presentation of the Beatitudes. - Trans.]

${ }^{21}$ [Up until this point in the text, Caso has been using "charity" [la caridad], but here he uses the more general term "love" [el amor] for the first time, suggesting in a broader way that the supernatural work of God and humans redeems, revolutionizes, or otherwise transforms the economic order of the world.-Trans.] 
one could truly say that it all amounts to the same thing because faith is immediate, the concomitant of charity. Good works, when they are reflected in the consciousness of he who practices them, are faith itself:

And if I have the gift of prophesy, and understand all mysteries, and all knowledge, and if I have all faith, so as to be able to move mountains, but do not have charity, I am nothing.

And if I divide up all of my estate to give food to the poor; and if I give my body over to be burned, but do not have charity, it is of no use.22

Like charity, which is the crown of virtue, hope, the wisdom [sagesse in French] of the Christian is the most philosophical and thoughtful of all the virtues, much greater than Socratic wisdom. The astronomer believes in the return of celestial bodies for only one reason-because they have previously retumed-and he hopes that they will consistently return in the same way. The believer believes in the perennial nature of the good - that the good will always return - for the same reason: because good actions were committed previously, are committed today, and will be committed tomorrow and forever.

There is no disorder in the world, only diverse orders, as Bergson would say. Sacrifice would be a disorder of life, which is pure economy. Life would be a disorder of charity. But the fact is that, to the postulate of the uniformity of nature, the postulate of the uniformity of charity should be added. Hope is an induction like the inductions of the sciences: the world and its laws on the one side, providence and its action on the other. He who hopes knows that today, tomorrow, and always men will sacrifice themselves to prevent the suffering of their neighbors; knows that men will always commit good actions; knows that spirits will always spend lavishly outside of themselves, that all moral value will be conserved indefinitely on God's diamond table. How could he not have this hope, if he himself is conscious of his capacity to do good insofar as he realizes it? "Charity," says Saint Paul, "never ends, even though prophecies will end, tongues will cease, and sciences will disappear." ${ }^{23}$ And Chrysostom comments in his beautiful homily De perfecta caritate: "It is not words alone, but deeds, that teach charity."

There is, therefore, a single law of the moral world: love. Not the profoundly interested biological love that is, in short, hunger (economy of the species if not of the individual). Not love of what is near, but rather of the neighbor, of the distant, as Nietzsche would say. Not love of the flesh for pleasure, not love of the other sex nor love of family. Strictly speaking, there are no precepts of love, as

\footnotetext{
${ }^{22} 1$ Corinthians 13:2-3.

${ }^{23} 1$ Corinthians 13:8.
}

Stirner teaches. One loves because love is supernatural, because man is supernatural. This is the sense in which Jesus spoke: "Who is my mother, and who are my brothers?" And stretching out his hand toward his disciples, he said: "Here are my mother, and my brothers.... Because everyone who does the will of my father, who is in heaven, is my brother, and sister, and mother."24

According to Tolstoy's interpretation, enthusiasm, love, projection beyond oneself, and Christian charity must be pure; they must be free from all violence and all bargaining with life. There is nothing more undilutedly Christian than these paragraphs:

That which men who do not understand existence call love consists in the predominance of certain conditions of personal well-being over any others. If the man who does not understand life says that he loves his wife, his children, his friends, he is only saying that the presence of his wife, his children, or his friends in his life improves his personal well-being.

True love is the renunciation of personal well-being. It consists in a state of benevolence toward all men, such as that which is typical of children but only appears in adults through self-abnegation.

What living man does not know-even if he has only felt it once during his earliest childhood-what man has not experienced this feeling of emotion, when one wants to love everything: neighbor, father, mother, brothers, evil men, dog, horse, grass? When one wants everything to go well, for everyone to be happy; even more, when one would like to find oneself in the situation of making everyone in the world happy; when one would like to sacrifice oneself, to hand over one's own life so that all would be well, overflowing with happiness? Precisely this, and this alone, is what constitutes the love that comprises human life.

Such is the Franciscan feeling of existence; such is the Saint of Assisi, the Christianizer of not only humanity but of all nature, the archetype of the contagious happiness of the Christian. In this way, the supernatural order falls upon the biological and inundates it with divine force.

"Do not resist evil" signifies: never resist the evildoer. In other words, never do violence to another, that is, never carry out an act that contradicts love. Christian love does not prohibit the struggle against evil, but rather the violent struggle against evil. ${ }^{25}$

${ }^{24}$ Matthew 12:48-50.

${ }^{25}$ See Anarchism According to Its Most Illustrious Representatives by P. Eltzbacher, the entry marked "Tolstoy." [Caso is drawing upon a Spanish translation of Pablo Eltzbacher's German original, which 
Tolstoy's doctrine is the systematic enunciation of the final verses of the fifth chapter of the Gospel according to Saint Matthew:

You have heard that it was said to the ancients: eye for eye; tooth for tooth. But I say to you: do not resist evil: when facing anyone who strikes you on your right cheek, turn to him the other as well.

You have heard that it was said: you shall love your neighbor, and abhor your enemy.

Now I say to you: love your enemies, bless those who curse you, do good to those who abhor you, and pray for those who slander you and persecute you.

In order that you may be sons of our father in heaven, who makes his sun rise on the evil and the good, and sends rain on the just and the unjust.

For if you love those who love you, what reward will you have? Do not the tax collectors also do the same?

And if you greet only your brothers, what more will you do? Do not the tax collectors also do this?

$\mathrm{Be}$, then, perfect, as your father in heaven is perfect.

Be perfect, that is to say, be active, charitable. ${ }^{26}$ "Perfect" signifies the completion of action, accomplished, realized. It signifies everything in actu, nothing in potentia. God, according to Aristotle and Saint Thomas Aquinas, is pure act.

Be like God, the verse teaches. Be pure act, perfect in the accomplishment of your ends, within your limited perfection. Do not hold on to something virtual. Live in your works. Throw yourselves into constant charitable action, like our father in heaven who is perfect and still works, according to Jesus. This interpretation is deduced from the same expression of Matthew: "Be, then, perfect ...," as if to say, be lovers with no strings attached, without limit, without measure. Realize yourselves as abnegation.

consists largely of extended quotations from Tolstoy. The lines selected by Caso come from an 1884 work by Tolstoy that has been published in English under at least three different titles: What I Believe; My Religion; and My Faith. Eltzbacher's article is also Caso's source for the previous block quotation from Tolstoy's On Life. - Trans.]

${ }^{26}$ [Caso's imperative, "Be perfect," is addressed to all of his readers in the plural. It grammatically mirrors the quoted verses from Matthew, where all verbs also appear in the second-person plural, with some even repeating the subject-vosotros (the plural form of "you," i.e., "you all"), which is already contained in the verb endings-for emphasis. The full effect is lost in translation because standard English uses "you" for the second-person singular and plural interchangeably, and English verb endings do not communicate their subjects as clearly.
Reader: ${ }^{27}$ what is said here is only philosophy, and philosophy is an interest of knowledge. Charity is action. Go and commit acts of charity. Then, more than sage, you will be saint. Philosophy is impossible without charity, but charity is perfectly possible without philosophy because philosophy is an idea, a thought, and charity is an experience, an action. Your century is egoist and perverse. Nevertheless, love the men of your century who seem no longer to know how to love, who only work by hunger and greed. He who commits a good act knows that the supernatural exists. He who does not do it will never know. All the philosophies of the men of science are worth nothing compared to the disinterested action of one good man.

\footnotetext{
${ }^{27}$ [Here and throughout his final paragraph, Caso calls each individual reader to a life of charity by using the second-person singular, which is a less formal and more intimate form of address. Caso's essay as a whole thus enacts an extended movement from the impersonal third-person world of existence as economy to the intimate second-person world of existence as charity, all subtly performed by shifts in verbal grammar. The beginning of Caso's essay is dominated by third-person impersonal verbs, which describe an economic world populated by egoistic creatures that are nevertheless devoid of personality. The middle of Caso's essay transitions away from this "vulgar" and impersonal consumer of the world to the artist, in whose soul the world still appears impersonally but now as beautiful in its own right, apart from any question of economic usefulness. The third and final part of the essay addresses readers in an increasingly personal way, with Caso moving from the secondperson plural to the second-person singular in the final paragraph. - Trans.]
} 